Images in...

\title{
Cardiac hydatid disease in the third world
}

\author{
Katy Juttner, ${ }^{1}$ Lara McKenzie, ${ }^{2}$ Neelam Razzak, ${ }^{3}$ Eberhadt Zehyle, ${ }^{4}$ Michael Belliere, ${ }^{5}$ David Anderson, ${ }^{6}$ \\ Robert Tulloh ${ }^{7}$
}

${ }^{1}$ University Hospitals Bristol NHS Foundation Trust, Bristol, UK;

2University of Bristol, Bristol, UK:

3University Hospitals Bristol, Bristol, UK;

${ }^{4}$ AMREF, Turkhana, Kenya;

${ }^{5}$ MEAK, Kenley, UK;

${ }^{6}$ Department of Cardiac Surgery, Guys and St Thomas Hospitals NHS Foundation Trust, London, UK;

${ }^{7}$ Department of Paediatric Cardiology, University Hospitals Bristol NHS Foundation Trust, Bristol, UK

Correspondence to Robert Tulloh, roberttulloh@btinternet.com

\section{DESCRIPTION}

Hydatid disease is caused by infection with the tapeworm Echinococcus granulosus. At 5-10\%, the prevalence rate in Kenya's Turkana region is among the highest worldwide. ${ }^{1}$ Infection involves cyst formation in many sites of the body, with cardiac hydatid disease being rare $(1 \%$ of all hydatid infestations) but potentially fatal. ${ }^{2}$

We report the case of a man in his late 30 s, referred by one of the authors for management of cardiac hydatid disease. He had presented to his local clinic with exertional angina, occasional haemoptysis and shortness of breath. An interventricular cyst had been demonstrated on ultrasound, and the patient was transported by flying doctor to our charity-based Kenyan heart surgery centre.

Clinically, we found the man to be healthy, with cardiac and respiratory examination being unremarkable. Hydatidosis was diagnosed on echocardiography, with a $4.9 \times 4.7 \mathrm{~cm}$ immobile cyst located in the interventricular septum (figure 1). ECG revealed ST segment depression and $\mathrm{T}$ wave inversion in leads $\mathrm{V}_{5}$ and $\mathrm{V}_{6}$. Chest radiography
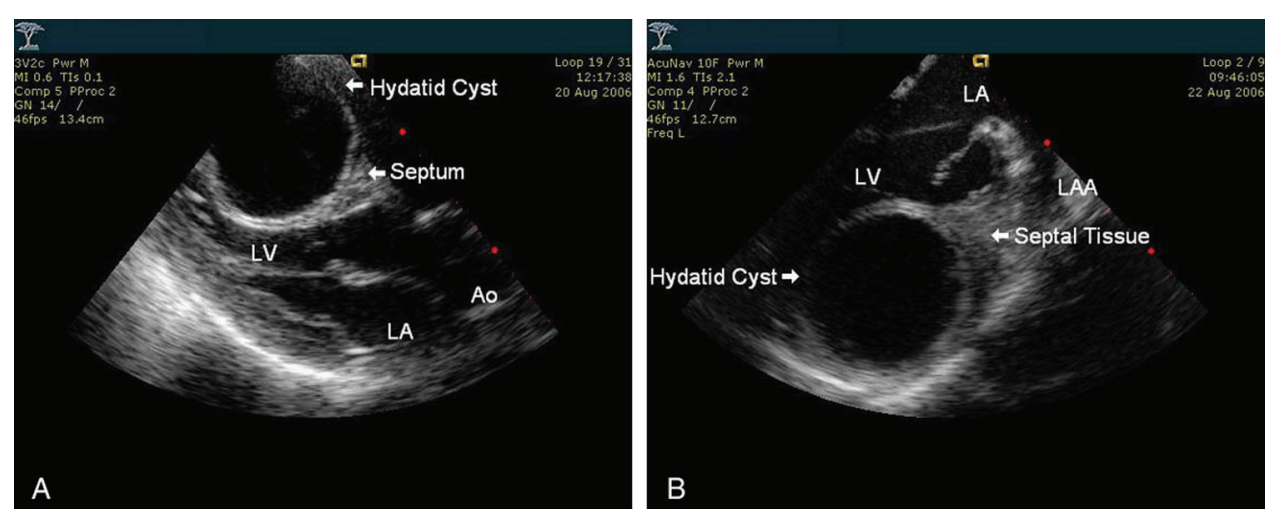

Figure 1 ( $A$ and $B$ ) Echocardiogram showing interventricular cyst. and ultrasound demonstrated two cysts within the right pleural cavity. Abdominal ultrasound was normal and CT unavailable.

On cardiopulmonary bypass, the anterior descending coronary artery was found to be crossing anteriorly to the cyst, explaining the unusual presentation of the cyst with angina. Only around four cases of cardiac hydatid disease presenting with angina have been reported, with only one due to an interventricular cyst. ${ }^{3}$

Cystopericystectomy was performed with a fine needle, aspirating the contents $(15 \mathrm{ml})$ before removing the pericyst (figure 2). The patient later underwent a thoracotomy to remove the pulmonary cysts, making a satisfactory recovery and returning to normal activities.

Acknowledgements The authors acknowledge the work undertaken by the team at the Kenyatta National Hospital in facilitating this treatment.

Competing interests None.

Patient consent Not obtained. 


\section{BMJ Case Reports}

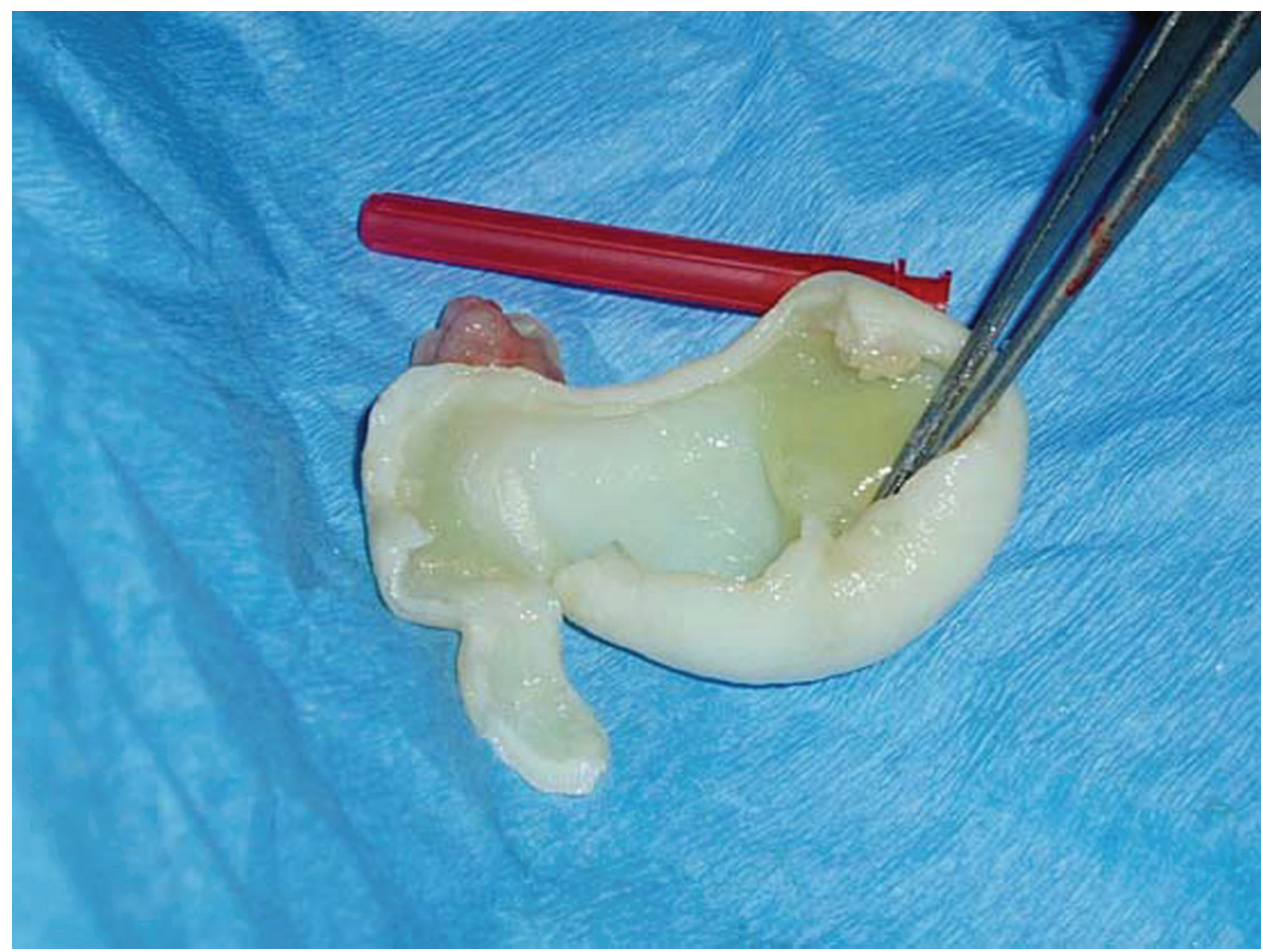

Figure 2 The pericyst after aspiration of its contents.

\section{REFERENCES}

1. Nelson GS. Hydatid disease: research and control in Turkana, Kenya. 1.

Epidemiological observations. Trans R Soc Trop Med Hyg 1986;80:177-82.

2. Perez-Gomez F, Duran H, Tamames S, et al. Cardiac echinococcosis: clinical picture and complications. Br Heart J 1973;35:1326-31.

This pdf has been created automatically from the final edited text and images.

Copyright 2011 BMJ Publishing Group. All rights reserved. For permission to reuse any of this content visit http://group.bmj.com/group/rights-licensing/permissions.

BMJ Case Report Fellows may re-use this article for personal use and teaching without any further permission.

Please cite this article as follows (you will need to access the article online to obtain the date of publication).

Juttner K, McKenzie L, Razzak N, Zehyle E, Belliere M, Anderson D, Tulloh R. Cardiac hydatid disease in the third world. BMJ Case Reports 2011;10.1136/bcr.12.2010.3609, date of publication

Become a Fellow of BMJ Case Reports today and you can:

- Submit as many cases as you like

- Enjoy fast sympathetic peer review and rapid publication of accepted articles

- Access all the published articles

- Re-use any of the published material for personal use and teaching without further permission

For information on Institutional Fellowships contact consortiasales@bmjgroup.com

Visit casereports.bmj.com for more articles like this and to become a Fellow 